\title{
Accumulation of Regulatory T Cells in Local Draining Lymph Nodes of the Lung Correlates with Spontaneous Resolution of Chronic Asthma in a Murine Model
}

\author{
William F. Carson IV ${ }^{a}$ Linda A. Guernsey ${ }^{a}$ Anurag Singh ${ }^{a} \quad$ Anthony T. Vella $^{a}$ \\ Craig M. Schramm ${ }^{\text {b }}$ Roger S. Thralla \\ Departments of a Immunology and ${ }^{b}$ Pediatrics, University of Connecticut Health Center, Farmington, Conn., USA
}

\section{Key Words}

Adoptive transfer · Allergic airway inflammation · Foxp3 •

Lymphocytes $\cdot$ Mouse $\cdot$ Ovalbumin $\cdot$ Regulatory T cells

\begin{abstract}
Background: Mice sensitized to ovalbumin develop allergic airway disease (AAD) with short-term aerosol challenge; however, airway inflammation resolves with long-term aerosol challenge, referred to as local inhalational tolerance (LIT). Methods: We sought to determine if resolution of airway inflammation correlated with increases in lymphocyte subsets in local lung compartments, including putative regulatory $T$ cells. Results: At the AAD stage, total numbers of $T$ and $B$ lymphocytes in bronchoalveolar lavage (BAL) were significantly increased above controls; however, at LIT, T and B lymphocytes were significantly reduced compared to AAD. In the lung tissue, the only alteration was a significant increase in CD4+ CD25+ T cells at AAD. In the hilar lymph node (HLN), CD4+ and CD4+ CD25+ T cells were significantly increased at AAD and LIT. In addition, CD8+ T cells were significantly
\end{abstract}

Abbreviations: $A A D=$ Allergic airway disease; $A P C=$ antigen-presenting cell; $B A L=$ bronchoalveolar lavage; $H L N=$ hilar lymph node; ILN = inguinal lymph node; LIT = local inhalational tolerance; OVA = ovalbumin; RAG = recombination activating gene; $\mathrm{T}_{\text {eff }}=$ effector $\mathrm{T}$ cell; $T_{\text {reg }}=$ regulatory $T$ cell.

\section{KARGER}

๑ 2007 S. Karger AG, Basel

Fax +41613061234

E-Mail karger@karger.ch

www.karger.com
Accessible online at:

www.karger.com/iaa elevated in the HLN at LIT, and CD19+ B cells were significantly increased at AAD. Adoptive transfer of HLN lymphocytes to lymphopenic mice confirmed that AAD lymphocytes could induce airway inflammation in response to aerosol challenge, whereas LIT lymphocytes were unable to do so. Depletion of CD4+ CD25+ T cells in vivo resulted in exacerbation of inflammation at AAD and LIT. CD4+ CD25+ $T$ cells in the HLN also displayed suppressive activity in vitro. Additionally, T cells expressing Foxp3 were increased in the BAL and HLN during LIT. Conclusions: These results indicate that lymphocytes with regulatory functions are increased and sustained in local lung compartments at LIT and that their appearance correlates with the resolution of lung inflammation.

Copyright $\odot 2007$ S. Karger AG, Basel

\section{Introduction}

Asthma is a serious health concern in developed countries and urban centers, with morbidity and mortality remaining high despite many recent advances in our understanding of its pathogenesis. Current therapies are symptom based, generally anti-inflammatory, and variably effective. Novel treatments that affect specific mechanisms of acute and chronic asthma are desirable, and experimental models of asthma that involve the entire

Correspondence to: Dr. William F. Carson IV

Department of Pathology, University of Michigan

Ann Arbor, 4710 BSRB 2200, 109 Zina Pitcher Place

Ann Arbor, MI 48109 (USA)

Tel. +1 734936 1020, Fax +1 734764 2397, E-Mail wfcarson@umich.edu 
spectrum of the disease process have broad implications for human health.

To cope with inhaled viruses, bacteria, noxious agents and allergens, the respiratory system has developed specialized defense mechanisms that form the basis of the mucosal immune system in the lung. To avoid a continuous inflammatory state that has the potential to cause tissue damage, the lung must discriminate between harmful and innocuous stimuli. Hence, the standard immune response to inhaled or ingested foreign materials is tolerance induction, whereby subsequent adaptive immune responses to allergen are suppressed through inactivation of adaptive immune effector functions. Antigen processing and presentation by steady-state antigen-presenting cells (APCs) in the mucosal surfaces, including the epithelium of the lung and intestine, result in inactivation of antigen-specific T cells through suboptimal costimulation, among other mechanisms [1-3]. One classic example of tolerance induction in allergy is oral tolerance, whereby oral exposure to antigens results in a suppression of allergic sensitization and subsequent antigen-specific inflammation in the lung in response to inhalational exposure [4]. In many cases, including oral tolerance, allergen exposure after sensitization results in an exacerbation of disease, indicating that similar tolerance induction mechanisms in allergy must occur prior to sensitization [5]. A better understanding of tolerance induction in models of allergic airway disease (AAD) should render valuable information and provide clues to possible therapeutic interventions.

Our laboratory and others have reported that mice sensitized to ovalbumin (OVA) develop AAD in response to short-term (3-10 days) aerosol exposure. The acute response is characterized by airway hyperresponsiveness, specific serum IgE antibody titers, peribronchial and perivascular lung inflammation, and elevated bronchoalveolar lavage (BAL) levels of $\mathrm{T}_{\mathrm{H}} 2$ cytokines and inflammatory cells, predominantly lymphocytes and eosinophils [6-11]. In contrast, OVA-sensitized mice that are chronically exposed to OVA-aerosol challenge for an extended period of time (42 days) exhibit resolution of airway inflammation, with a significant decrease in lung eosinophilia and a reversal of airway hyperresponsiveness $[6,7,12,13]$. This resolution of AAD may be associated with the development of a form of immunologic tolerance that downregulates the proinflammatory CD4+ effector $\mathrm{T}$ cells $\left(\mathrm{T}_{\text {eff }}\right)$. The immune mechanism remains unclear, but it appears to be restricted to the local lung environment, since OVA-specific IgE and $\mathrm{IgG}_{1}$ levels in serum remain elevated above levels seen in OVA-sensi- tized mice prior to aerosol challenge [7]. This reversal of $\mathrm{AAD}$ in response to long-term aerosol exposure has been termed local inhalational tolerance (LIT), due to the distinct differences in local versus systemic immune responses and the necessity of continuous OVA-aerosol exposure [7].

In contrast to the reduction in eosinophils in the BAL at LIT, lymphocyte levels in the BAL remain elevated compared to naive mice $[6,7]$. We hypothesize that these lymphocytes play an integral role in the development of LIT, since their persistence in BAL correlates with the resolution of airway inflammation. Of particular interest are regulatory $\mathrm{T}$ cells $\left(\mathrm{T}_{\text {reg }}\right)$, since they have been shown to modulate airway inflammation in numerous animal models [14-18], including AAD [14, 15, 18-22]. Specifically, $\mathrm{T}_{\text {reg }}$ can suppress airway inflammation through the use of anti-inflammatory cytokines such as IL-10 [22-24] and TGF- $\beta$ [25-28]. These cells have also been shown to be increased in murine tolerance models involving aerosol challenge prior to sensitization with adjuvant [28]. The purpose of this study was to determine if shifts in lymphocyte populations occurred in various local and systemic tissues at AAD and LIT, including putative $T_{\text {reg }}$ populations, which would support their role in the development of LIT and resolution of inflammation.

\section{Methods}

\section{Animals}

Female C57BL/6 mice, 3-4 months of age and weighing 15$20 \mathrm{~g}$, were purchased from the Jackson Laboratory (Bar Harbor, Maine, USA) and housed conventionally in plastic cages with corncob bedding. The animal room was maintained at $22-24^{\circ} \mathrm{C}$ with a daily light/dark cycle. Chow and water were supplied ad libitum. The protocols for animal use were approved by the Animal Care Committee at the University of Connecticut Health Center.

OVA Exposure Protocol [29]

Mice were immunized with 3-weekly intraperitoneal injections of a suspension containing $25 \mu \mathrm{g}$ of OVA (grade V; Sigma, St. Louis, Mo., USA) and $2 \mathrm{mg}$ of aluminum hydroxide (alum) in $0.5 \mathrm{ml}$ of saline. One week after the last injection, the mice were exposed to $1 \%$ aerosolized OVA in physiologic saline for $1 \mathrm{~h}$ /day for either 7 (AAD) or 42 days (LIT). The aerosols were generated by a BANG nebulizer (CH Technologies, Westwood, N.J., USA) into a 7.6-liter nose-only inhalation exposure chamber to which individual restraint tubes were attached. Chamber airflow was $6 \mathrm{l} / \mathrm{min}$, and aerosol particle size of OVA was monitored by gravimetric analysis with a Mercer cascade impactor (In-Tox Products, Moriarty, N. Mex., USA). The mass median aerodynamic diameter and geometric standard deviations were 1.4 and $1.6 \mu \mathrm{m}$, respectively. The estimated daily inhaled OVA dose approximat- 
ed 30-40 $\mu \mathrm{g} / \mathrm{mouse}$. Twenty-four hours after the final aerosol exposure, the mice were killed by ketamine/xylazine overdose and subsequent exsanguination. Definitions of exposure designations are as follows: AAD $=7$ days of OVA aerosol, and LIT $=42$ days of OVA aerosol.

\section{BAL/Tissue Analysis}

At sacrifice, BAL fluid, lung tissue, local lung lymph nodes (hilar lymph node; HLN), systemic lymph nodes (inguinal lymph node; ILN) and spleens were harvested and processed for the isolation and enumeration of leukocytes. For collection of BAL, lungs were lavaged in situ with five 1-ml aliquots of physiologic saline. The BAL fluid was centrifuged, the cellular pellet washed, and total isolated leukocytes were saved for analysis. For analysis of lung tissue, mice were perfused with phosphate-buffered saline (PBS)/heparin prior to dissection. Lungs were removed, minced, and digested in collagenase (150 U/ml; Invitrogen, Carlsbad, Calif., USA), and the cellular suspension was separated on a Percoll (Sigma) density gradient for the isolation of lymphocytes. Lymph nodes and spleens were harvested and mechanically disrupted into a single-cell suspension. Hypotonic lysis was used to eliminate erythrocytes. For all tissue samples, total nucleated cell counts were obtained using a hemocytometer with nigrosin dye exclusion as a measure of viability.

\section{Flow Cytometry and Immunofluorescence}

Cells isolated from the BAL and other tissues were analyzed via flow cytometry using the following monoclonal antibodies: anti-CD8a-FITC (53-6.7), anti-CD25-PE (PC61), anti-CD4PerCP (RM4-5), anti-CD4-PeCy7 (RM4-5), anti-CD3e-PerCPCy5.5 (145-2C11), anti-CD19-PE (1D3), and anti-CD19-PerCPCy5.5 (1D3). Samples were washed in PBS containing $0.2 \%$ bovine serum albumin and $0.1 \% \mathrm{NaN}_{3}$. Aliquots containing $10^{4}-10^{6}$ cells were incubated with $100 \mu \mathrm{l}$ of appropriately diluted antibodies for $30 \mathrm{~min}$ at $4^{\circ} \mathrm{C}$. After staining, the cells were washed with the above $\mathrm{PBS}$ solution, and relative fluorescence intensities were determined on a 4 -decade log scale by flow-cytometric analysis using a FACSCalibur or LSR II (Becton-Dickinson, San Diego, Calif., USA). In separate experiments, for the identification of $\mathrm{T}_{\text {reg, }}$ intracellular staining of Foxp3 protein was used. Briefly, cells stained with the antibodies mentioned previously (i.e. anti-CD3e, anti-CD4, and anti-CD25) were permeabilized using fixation/ permeabilization buffer following the manufacturer's protocol, and stained using either anti-Foxp3-FITC (FJK-16s) or antiFoxp3-APC (FJK-16s) with corresponding isotype controls, IgG2a-FITC or -APC (eBioscience, San Diego, Calif., USA).

\section{Adoptive Transfer}

HLN cells isolated from AAD and LIT mice were pooled separately and processed into a single-cell suspension. Recipient RAG1-/- mice were given $2 \times 10^{7}$ total lymphocytes in sterilized PBS via tail vein injections. Mice were allowed to rest for 4 days post-transfer prior to the start of aerosol challenge. When indicated, recipient mice received 7 days of OVA-aerosol challenge. Recipient mice were sacrificed $24 \mathrm{~h}$ after the final aerosol challenge, BAL fluid was collected and viable cells were counted as previously described. Cytospin preparations of BAL fluid were stained with May-Grünwald and Giemsa for differential cell analysis via light microscopy.

\section{Histology}

After sacrifice, unmanipulated (not subjected to BAL) and non-inflated lungs from separate animals were removed, fixed with $10 \%$ formalin, and processed in a standard manner. Tissue sections were stained with hematoxylin and eosin for standard evaluation.

$T_{\text {reg }}$ in vitro Functional Assay

A standard $\mathrm{T}_{\text {reg }}$ functional assay with $\mathrm{T}_{\text {eff }}, \mathrm{T}_{\text {reg }}$ and irradiated splenocytes as a source of APCs was used as previously described [30]. Purified populations of CD4+ CD25- ( $\left.\mathrm{T}_{\mathrm{eff}}\right)$ and CD4+ CD25+ T cells $\left(\mathrm{T}_{\text {reg }}\right)$ from spleens and lymph nodes of mice were obtained using iron microbead-conjugated antibodies (Miltenyi Biotech, Auburn, Calif., USA) with subsequent magnetic separation on columns following the manufacturer's protocol. Purity of isolated cells was $\geq 90 \%$ for each separation (data not shown). $T_{\text {eff }}$, $\mathrm{T}_{\text {reg, }}$, and APCs (CD4+ T cell-depleted, 2,600-rad-irradiated splenocytes) were plated in round-bottom 96-well plates in RPMI 1640 (Sigma-Aldrich, St. Louis, Mo., USA) supplemented with $10 \%$ FCS, penicillin-streptomycin (Cellgro, Herndon, Va., USA), L-glutamine, HEPES, gentamicin (BioWhittaker, East Rutherford, N.J., USA), and $5 \times 10^{-5}$ M 2-mercaptoethanol (Sigma). Each cell population was used in triplicate wells at $1 \times 10^{5}$ cells/well. Cultures were stimulated with $0.65 \mu \mathrm{g} / \mathrm{ml}$ soluble anti-CD3 antibody (BD Biosciences) for $48 \mathrm{~h}$, and $0.2 \mu \mathrm{Ci} /$ well ${ }^{3}[\mathrm{H}]$ thymidine was added for the last $12 \mathrm{~h}$. Cultures were harvested using a semiautomated cell harvester and assayed using a $\beta$-scintillation counter.

\section{PC61 Antibody Treatment}

For in vivo depletion of CD25+ T cells, mice were given a single dose $(0.5 \mathrm{mg}$ ) of PC61 antibody (rat anti-mouse IgG) in sterile PBS at the indicated time points via intraperitoneal injection. Control mice were given a single injection of control rat IgG antibody (Sigma). Flow-cytometric analysis of local and systemic tissues indicated that the depletion of CD25+ T cells in vivo was $\geq 98 \%$, and the depletion was observable up to 21 days after injection (data not shown). Two PC61 treatment protocols were designed: (1) to determine if CD4+ CD25+ T-cell depletion could inhibit the development of LIT after AAD was established, PC61 was administered on day 21 of daily OVA-aerosol challenge, and (2) since PC61 can deplete both $\mathrm{T}_{\text {reg }}$ and $\mathrm{T}_{\text {eff }}$ cells, treatment was given prior to sensitization and aerosol challenge, in an attempt to deplete CD4+CD25+ T cells prior to the development of CD25+ OVA-specific $\mathrm{T}_{\text {eff }}$. For analysis of PC61 treatment prior to sensitization, the following modifications were made to the sensitization and aerosol challenge protocol: total numbers of intraperitoneal OVA-alum injections were reduced from 3 to 2, and AAD mice were sacrificed after day 3 of continuous aerosol exposure instead of day 7. Previous studies indicate no effect of the reduced number of intraperitoneal injections on the severity of 3- or 7-day AAD lung inflammation in this model (data not shown).

\section{Statistical Analysis}

Analysis of variance (ANOVA) followed by post hoc twotailed Student's unpaired t tests was used for data analysis, with values of $\mathrm{p}<0.05$ used as the significance threshold. All statistical analysis was performed using the JMP IN 5.1 statistical software package (SAS Institute, Cary, N.C., USA). 


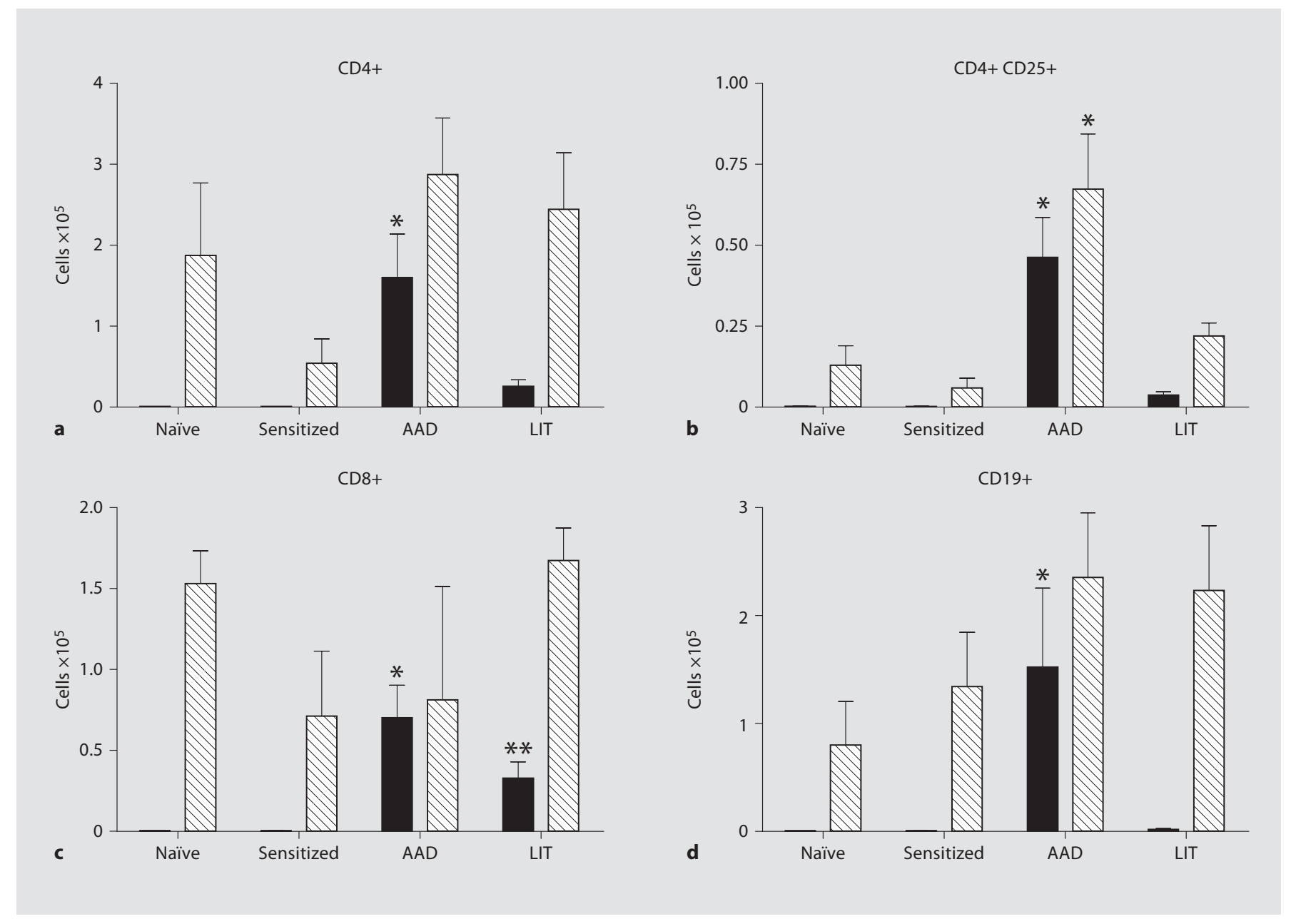

Fig. 1. Lymphocyte populations in BAL $(\square)$ and lung tissue $(\mathbb{\nabla})$ at AAD and LIT. Cells recovered from BAL fluid and whole lung tissue (not subjected to BAL) were analyzed for the presence of CD4+ (a), CD4+ CD25+ (b), CD8+ (c), and CD19+ (d) cells. Data represent the mean \pm SEM. ${ }^{*} \mathrm{p}<0.05$ vs. naïve/sensitized/LIT, ${ }^{* *} \mathrm{p}<$ 0.05 vs. naïve/sensitized/AAD. Six to eight mice were used in all groups.

\section{Results}

T- and B-Cell Numbers Were Increased in the BAL at $A A D$ and LIT

Previous reports have indicated that while BAL eosinophilia is greatly reduced in LIT mice, BAL lymphocytes remain elevated above naïve controls [7]. Analysis of BAL from sensitized mice showed no effect of intraperitoneal OVA-alum injections on the total numbers of CD4+, CD4+ CD25+, CD8+ T cells, or CD19+ B cells compared to naïve controls (fig. 1). In sensitized and OVA-aerosolized mice at the AAD stage, total numbers of CD4+ T cells in BAL $\left(1.60 \times 10^{5} \pm 0.5\right)$ were significantly increased above the barely detectible levels seen in naïve and sensitized-only mice (fig. 1a). Additional increases were observed in total numbers of CD4+ CD25+ $\mathrm{T}$ cells in BAL $\left(4.63 \times 10^{4} \pm 1.2\right)$ at AAD (fig. 1b). The numbers of CD4+ and CD4+ CD25+ T cells in BAL decreased significantly at LIT compared to AAD (fig. 1a, b). A similar significant increase was observed with CD8+ T cells, with a significant increase in BAL cells at AAD (7.0 $\left.\times 10^{4} \pm 1.7\right)$ compared to naïve and sensitized-only controls; in addition, the CD8+ T cells remained significantly elevated $\left(3.28 \times 10^{4} \pm 1.0\right)$ above those of control mice at LIT (fig. 1c). The number of B cells in BAL was also significantly elevated above naïve and sensitized levels at $\operatorname{AAD}\left(1.52 \times 10^{5} \pm 0.7\right)$, and returned to within normal levels at LIT $\left(0.02 \times 10^{5} \pm 0.001, \mathrm{p}<0.05\right.$; fig. 1d). 
CD4+

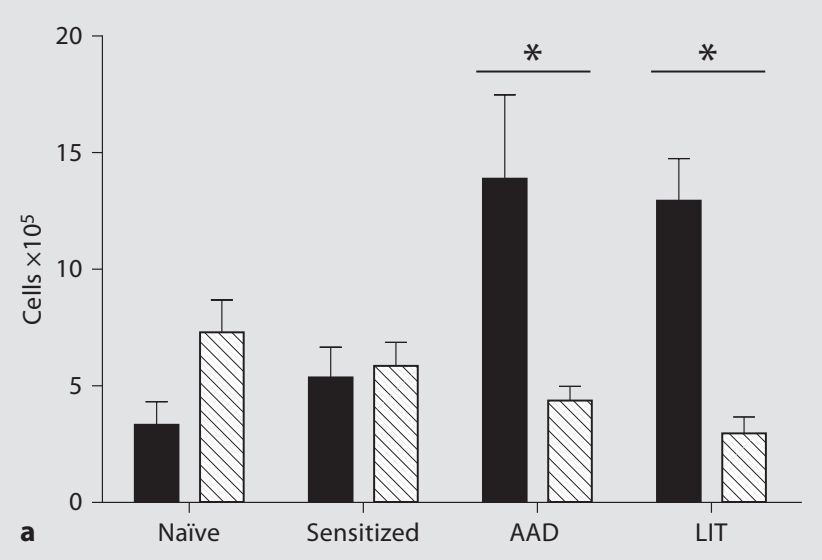

CD8+

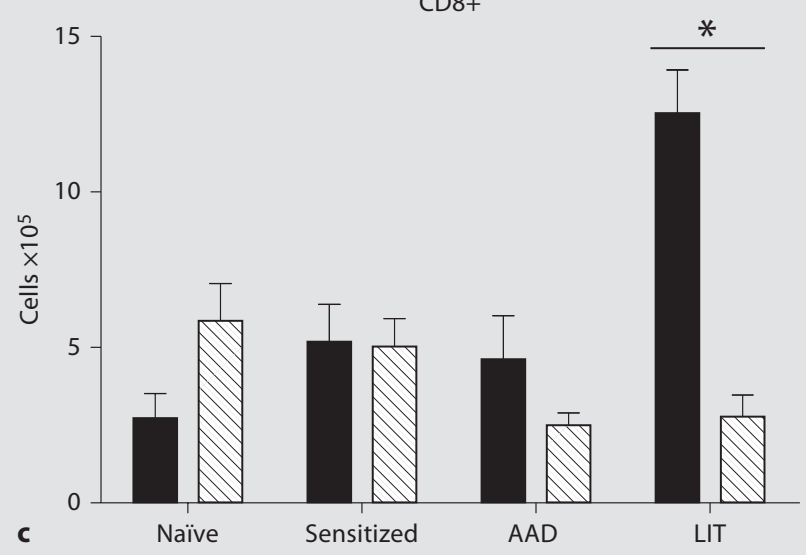

$\mathrm{CD} 4+\mathrm{CD} 25+$

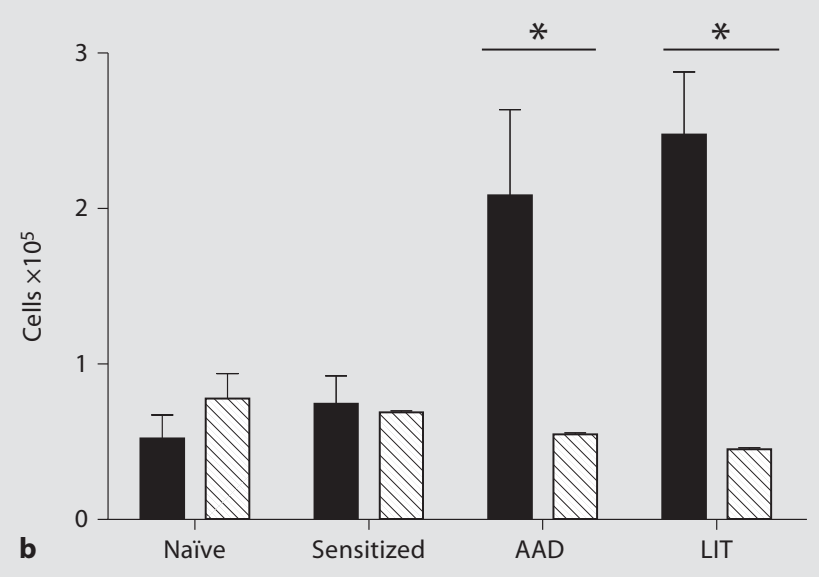

CD19+

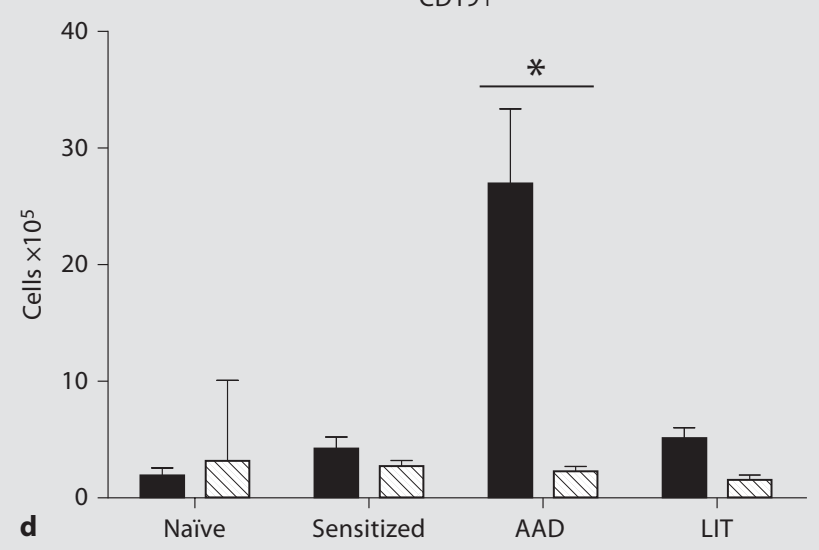

Fig. 2. Lymphocyte populations in HLN $(\square)$ and ILN $(\mathbb{\nabla})$ at the AAD and LIT stage. Cells recovered from each node were analyzed for the presence of CD4+ (a), CD4+CD25+ (b), CD8+ (c), and CD19+ cells (d). Data represent the mean \pm SEM. ${ }^{*} \mathrm{p}<0.05$ between nodes from each time point. Eight mice were used in all groups.

Similar to the BAL, sensitization alone did not significantly alter the numbers of CD4+, CD4+ CD25+, CD8+, or CD19+ B cells in the lung tissue compared to naïve levels (fig. 1). In a similar fashion as BAL, total numbers of CD4+ CD25+ T cells were increased in the lung tissue at $\mathrm{AAD}\left(6.73 \times 10^{4} \pm 1.7\right.$ for $\mathrm{AAD}$ vs. $1.34 \times 10^{4} \pm 0.6$ for naïve, $\mathrm{p}<0.05)$, with total cell numbers returning to naïve and sensitized levels at LIT (fig. 1b). However, in contrast to BAL, total numbers of CD4+ (fig. 1a), CD8+ $\mathrm{T}$ cells (fig. 1c), and CD19+ B cells (fig. 1d) were not significantly increased over naïve or sensitized levels at AAD or LIT.

T Lymphocytes and Resolution of Murine Asthma
T- and B-Cell Numbers Were Increased in the HLN at $A A D$ and LIT

Local lung (HLN) and systemic (ILN) lymph nodes from mice in each group were analyzed for the presence of $\mathrm{T}$ and $\mathrm{B}$ lymphocytes to determine if lymphocyte subpopulations differed at either the AAD or LIT stage. As with the BAL and lung tissue, total numbers of $\mathrm{T}$ and $\mathrm{B}$ cells in both the HLN and ILN were unaffected by the sensitization protocol alone; moreover, there were no statistical differences between HLN and ILN in the total numbers of each lymphocyte subset analyzed in naïve or sensitized groups (fig. 2). In addition, no changes in Tand B-cell numbers were observed in the ILN in any group (fig. 2). In the HLN, total numbers of CD4+ (13.87

Int Arch Allergy Immunol 2008;145:231-243 
Fig. 3. Adoptive transfer of HLN lymphocytes in RAG1-/- mice. HLN lymphocytes $\left(2 \times 10^{7}\right)$ from AAD or LIT mice were transferred to RAG1-/- mice via tail vein injection. Recipient mice were allowed to rest for 4 days post-transfer prior to challenge with 1\% OVA aerosol for 7 days (AAD). Recipient mice were sacrificed, and BAL fluid was collected and analyzed via differential cell counts for the presence of macrophages ( $\square$ ), neutrophils ( $\square$ ), lymphocytes $(\square)$ and eosinophils $(\mathbb{\nabla})$. Data represent 5-12 recipient mice for each group. ${ }^{*} \mathrm{p}<0.05$ vs. naïve RAG1-/-.

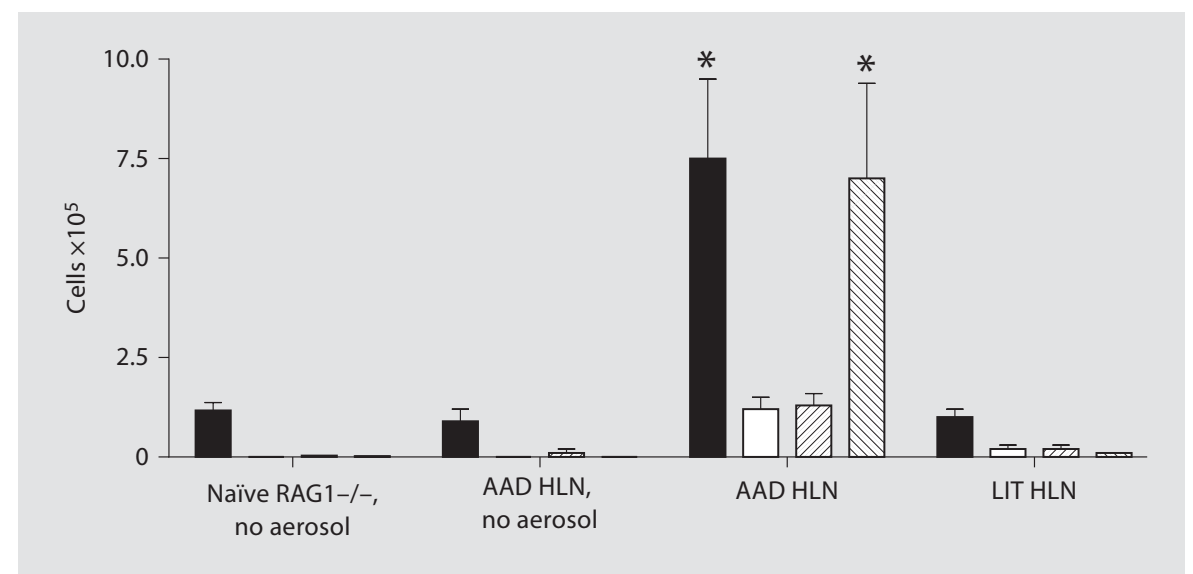

$\left.\times 10^{5} \pm 3.6\right)$ and $\mathrm{CD} 4+\mathrm{CD} 25+\left(2.08 \times 10^{5} \pm 0.6\right) \mathrm{T}$ cells were increased at AAD, and these levels were maintained at LIT $\left(12.92 \times 10^{5} \pm 1.8\right.$ and $2.48 \times 10^{5} \pm 0.4$, respectively) compared to both naïve or sensitized levels in HLN, and to ILN from the each group (fig. 2a, b). Interestingly, in contrast to observations in BAL and lung tissue, the total numbers of CD4+ and CD4+ CD25+ T cells remained significantly elevated at LIT in the HLN (fig. 2 a, b). In addition, levels of CD8+ T cells were only significantly increased in HLNs at LIT $\left(12.52 \times 10^{5} \pm\right.$ 1.4) compared to naïve control levels $\left(2.71 \times 10^{5} \pm 0.8\right.$; fig. 2c). Total numbers of CD19+ B cells were significantly increased in HLNs at AAD only $\left(26.95 \times 10^{5} \pm 6.4\right)$ compared to naïve controls $\left(1.90 \times 10^{5} \pm 0.6\right)$, and returned to naïve and sensitized levels at LIT $\left(5.09 \times 10^{5}\right.$ \pm 0.9 ; fig. $2 \mathrm{~d}$ ).

\section{Adoptive Transfer of HLN Lymphocytes from AAD} but Not LIT Mice Induce Airway Inflammation in Lymphopenic Mice in Response to Aerosol Challenge

The persistence of T lymphocyte subsets in the HLN at LIT appeared in contrast to the resolution of inflammation, suggesting a functional difference between $\mathrm{AAD}$ and LIT lymphocytes. To investigate functional differences, HLN lymphocytes isolated from AAD and LIT mice were adoptively transferred into lymphopenic mice (RAG1-/-) to assess their ability to induce airway inflammation in recipient mice, assessed by BAL differential and lung pathology. Naïve RAG1-/- mice and RAG1-/that received AAD HLN lymphocytes had no evidence of airway inflammation in the BAL in the absence of aerosol challenge (fig. 3). RAG1-/- mice that received AAD HLN lymphocytes exhibited airway inflammation upon OVAaerosol challenge, with significant increases in both mac- rophages $\left(7.5 \times 10^{5} \pm 2.0\right)$ and eosinophils $\left(7.0 \times 10^{5} \pm\right.$ $2.4)$ in the BAL compared to naïve RAG1-/- controls (fig. 3). In contrast, transfer of equivalent numbers of LIT HLN lymphocytes did not result in airway inflammation in response to aerosol challenge, with levels of macrophages and eosinophils remaining similar to unchallenged RAG1-/- mice (fig. 3). These findings were substantiated by evaluation of lung histology of animals from each group, confirming the appearance of peribronchial and perivascular inflammation with eosinophilia in recipient mice receiving AAD HLN lymphocytes, with no injury apparent in recipient mice receiving LIT HLN lymphocytes (fig. 4).

\section{CD4 + CD25+ T Cells from the HLN Demonstrated in vitro Suppressive Activity \\ As LIT lymphocytes from the HLN were unable to me-} diate airway inflammation in response to aerosol challenge in recipient mice, we sought to determine if these HLN lymphocytes exhibited properties of $\mathrm{T}_{\text {reg. }}$. To confirm the regulatory function of CD4+ CD25+ T cells in the HLN at AAD and LIT, we isolated these cells for use in an in vitro $\mathrm{T}_{\text {reg }}$ functional assay using CD4+ $\mathrm{CD} 25-\mathrm{T}$ cells $\left(\mathrm{T}_{\text {eff }}\right)$ from the spleens of naïve mice as responder cells. For comparison of in vitro suppressive function, $\mathrm{T}_{\text {reg }}$ from the spleens of naïve mice were used, as their suppressive activity in vitro has been well characterized [31]. Stimulation of naïve splenic $\mathrm{T}_{\text {eff }}$ with $\alpha$-CD3 resulted in robust proliferation, which was suppressed by the addition of naïve splenic $\mathrm{T}_{\text {reg }}$ (73.4\% reduction in proliferation) in a standard manner (fig. 5). Analysis of $\mathrm{T}_{\text {eff }}$ proliferation in the cocultures indicated that $\mathrm{T}_{\text {reg }}$ from both AAD and LIT HLN had suppressive function in vitro when equivalent numbers of these cells were used (49.8 

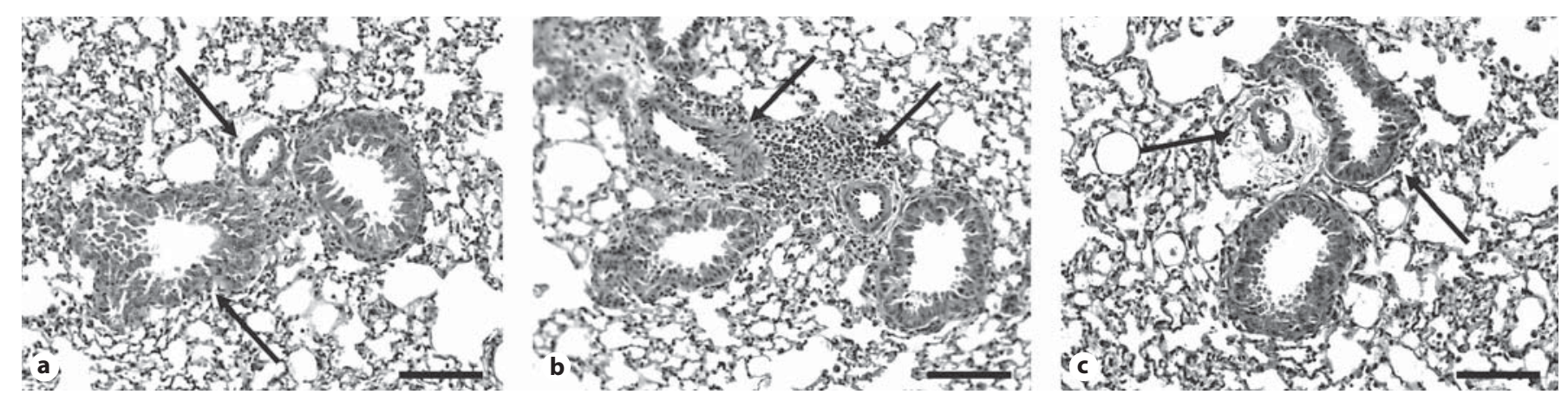

Fig. 4. Lung tissue histology from RAG1-/- recipient mice. Formalin-fixed lungs were processed in a standard manner and stained with H\&E. a AAD HLN, no aerosol. b AAD HLN with aerosol. c LIT HLN with aerosol. Arrows highlight the presence $(\mathbf{b})$ or absence $(\mathbf{a}, \mathbf{c})$ of perivascular and peribronchial inflammation. $\times 20$. Scale bar $=100 \mu \mathrm{m}$.

and $76.4 \%$ suppression, respectively; fig. 5). Suppression of naïve $\mathrm{T}_{\text {eff }}$ proliferation was similar between naïve splenic $\mathrm{T}_{\text {reg, }}, \mathrm{AAD}$ and LIT HLN $\mathrm{T}_{\text {reg }}$, indicating that CD4+ CD25+ T cells from both AAD and LIT HLNs have in vitro suppressive function.

Depletion of CD4+CD25+T Cells prior to OVA-Alum Sensitization Resulted in Increased BAL Eosinophilia at $A A D$ and LIT

To determine if the CD4+ CD25+ T cells in this model also exhibited in vivo suppressive activity in either AAD or LIT, an in vivo CD25+ T cell-depleting antibody was utilized. To test the hypothesis that CD4+ CD25+ T cells are essential for the maintenance of LIT, mice were treated with PC61 antibody on day 21 of the OVA model. Differential analysis of the BAL at LIT indicated no significant difference in the total number of macrophages, neutrophils, lymphocytes or eosinophils in the BAL of PC61-treated mice as compared to wild-type or rat IgGtreated mice (fig. 6a). In each case, eosinophils were largely absent in the airways, with no effect of PC61 treatment observed on total eosinophils (fig. 6a).

PC61 antibody is capable of depleting not only $\mathrm{T}_{\text {reg, }}$, but also other cells such as CD4+ and CD8+ $\mathrm{T}_{\text {eff }}$ that upregulate $\mathrm{CD} 25$ upon activation; therefore, in another experiment, mice were treated with PC61 1 week prior to the start of OVA-alum sensitization to limit the effect of antibody treatment on $\mathrm{T}_{\text {eff. }}$ PC61-treated mice exhibited a significant increase in eosinophils at $\mathrm{AAD}\left(25.81 \times 10^{5}\right.$ $\pm 8.5)$ compared to wild-type $\left(7.01 \times 10^{5} \pm 1.1\right)$ and rat IgG-treated $\left(2.82 \times 10^{5} \pm 0.9\right)$ controls, with no significant differences observed in other cell types (fig. 6b). Also, in this treatment protocol, PC61-treated mice

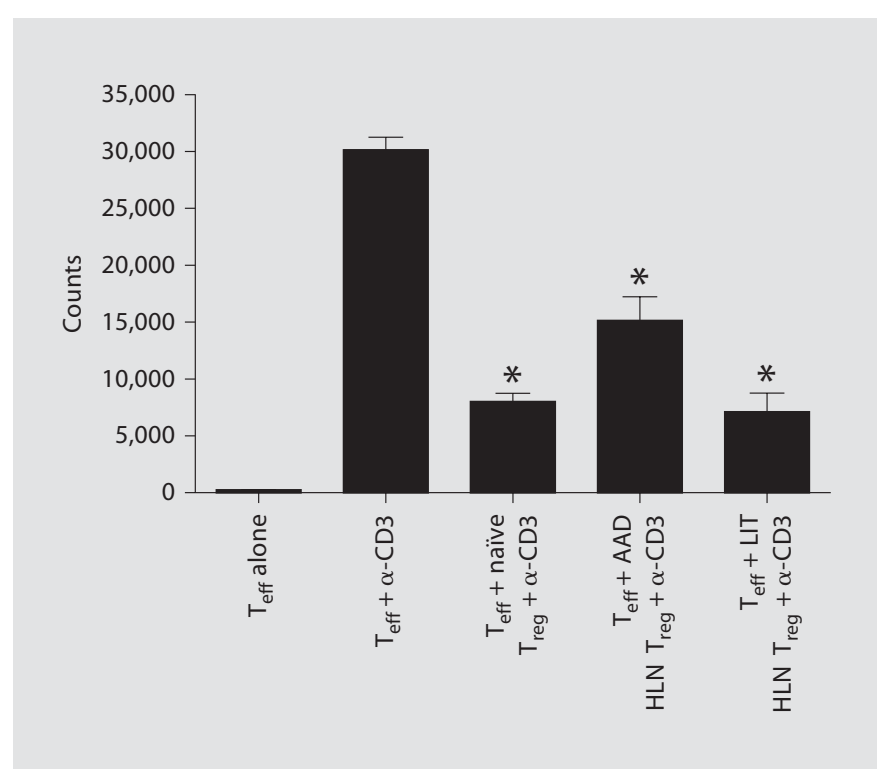

Fig. 5. CD4+ CD25+ T cells from HLN demonstrated in vitro suppressive activity. CD4+ CD25+ T cells from naïve spleens, AAD or LIT HLN were used in an in vitro suppression assay using naïve CD4+ CD25- T cells ( $\mathrm{T}_{\text {eff }}$ ) as responder cells, using ${ }^{3}[\mathrm{H}]$ thymidine labeling with subsequent analysis on a scintillation counter. Each cell population was used in triplicate wells at $1 \times 10^{5}$ cells/well. ${ }^{*} \mathrm{p}<0.05$ vs. $\mathrm{T}_{\text {eff }}$ and anti-CD3.

showed a significant increase in eosinophils $\left(1.60 \times 10^{5}\right.$ $\pm 0.5)$ at LIT, along with a significant increase in lymphocytes $\left(1.60 \times 10^{5} \pm 0.2\right.$; fig. $\left.6 \mathrm{c}\right)$. No effect on macrophages or neutrophils was observed in LIT mice treated with PC61 prior to sensitization (fig. 6c). 


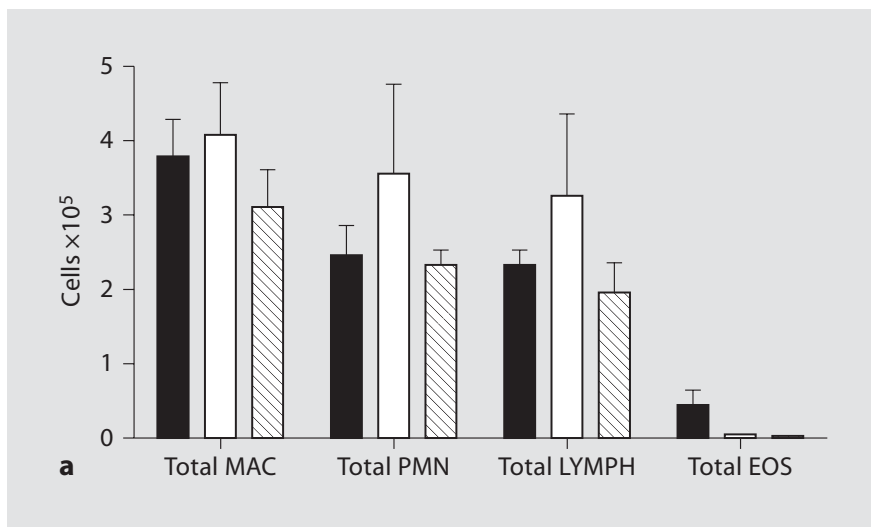

Fig. 6. PC61 treatment prior to OVA-alum sensitization results in increased eosinophilia at AAD and LIT. Mice were treated with either control antibody (Rat IgG; $\square$ ) or CD25+ T cell-depleting antibody (PC61; $\mathbb{\nabla})$ at the indicated time points and then subjected to OVA sensitization and aerosol challenge. a PC61 treatment on day 21 of continuous aerosol exposure, sacrifice on day 42 (LIT). b PC61 treatment prior to sensitization, sacrifice on day 3 (3-day AAD). c PC61 treatment prior to sensitization, sacrifice on day 42 (LIT). Mice were sacrificed, and BAL fluid was collected and analyzed via differential cell counts for the presence of macrophages (MAC), neutrophils (PMN), lymphocytes (LYMPH) and eosinophils (EOS). Data represent the mean \pm SEM. ${ }^{*} \mathrm{p}<$ 0.05 vs. all groups. Four to five mice were used in all groups. $\square=$ Control.

\section{Foxp3+ T Cells Were Increased in BAL and HLN at LIT}

As shown previously, CD4+ CD25 $+\mathrm{T}$ cells were increased in the BAL, HLN and lung tissue at AAD, and these numbers were maintained in the HLN at LIT (fig. 1b, 2b). To further characterize the CD4+CD25+ T cells as either $\mathrm{T}_{\text {reg }}$ or $\mathrm{T}_{\text {eff }}$, intracellular staining for Foxp3 protein was utilized. Flow-cytometric analysis of $\mathrm{T}$ cells showed a significant increase in total numbers of CD4+ CD25+ Foxp3+ T cells in the BAL at AAD $\left(2.40 \times 10^{3} \pm\right.$ $0.5)$ compared to naïve $\left(0.04 \times 10^{2} \pm 0.01\right)$ and sensitized $\left(0.17 \times 10^{2} \pm 0.1\right)$ levels (fig. 7a). Additionally, the BAL showed a significant increase in total numbers of CD4+ CD25+ Foxp3+ T cells at LIT $\left(6.40 \times 10^{3} \pm 2.6\right)$, in contrast to previous analysis (fig. 7a). However, in a similar fashion as CD4+ CD25+ T cells, the peak of CD4+ CD25+ Foxp3+ T cells in the lung tissue was at AAD (7.4 $\times 10^{4} \pm 1.9$; fig. $7 \mathrm{a}$ ).

In HLN, total numbers of CD4+ CD25+ Foxp3+ T cells increased at AAD $\left(11.4 \times 10^{4} \pm 1.0\right)$ and LIT $(25.4$ $\times 10^{4} \pm 3.0$ ), while levels of CD4+ CD25+ Foxp3+ T cells did not increase in ILN at either AAD $\left(3.02 \times 10^{4}\right.$
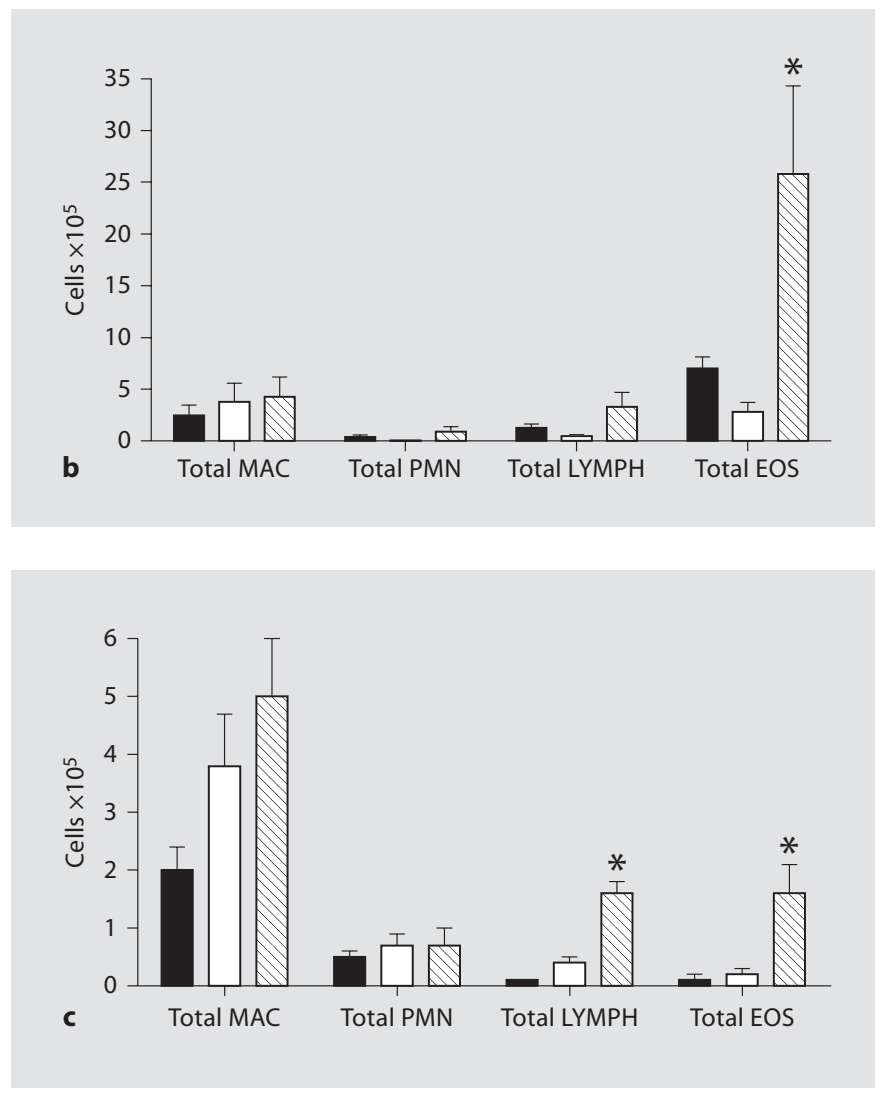

$\pm 0.6)$ or LIT $\left(2.72 \times 10^{4} \pm 0.8\right.$; fig. $\left.7 \mathrm{~b}\right)$. As observed in BAL, CD4+ CD25+ Foxp3+ T cells in the HLN were significantly increased at LIT compared with AAD. A slight increase in CD4+ CD25+ Foxp3+ T cells was detected in ILN after sensitization $\left(3.6 \times 10^{4} \pm 1.3\right)$; however, this increase was not found to be statistically significant from naïve levels $\left(0.50 \times 10^{3} \pm 0.2\right)$.

\section{Ratio of Total CD4 + CD25+ Foxp $3+T$ Cells Increased} in Local Lung Compartments from AAD to LIT

Previous studies have indicated that the progression from AAD to LIT in this model correlates with a shift in the CD4:CD8 T-cell ratio in the BAL, with a skewing towards CD4+ T cells during AAD and an equilibrium of T-cell subtypes during LIT [6]. To determine if similar shifts occurred with putative $\mathrm{T}_{\text {reg }}$, ratios of total numbers of CD8+ and CD4+ CD25+ Foxp3+ T cells to total CD4+ $\mathrm{T}$ cells were calculated and compared between local lung compartments during AAD and LIT.

As reported previously, the progression from $\mathrm{AAD}$ to LIT resulted in equilibrium of CD4+ and CD8+ T cells in BAL (approximately 2:1 at AAD and 1:1 at LIT); a similar 

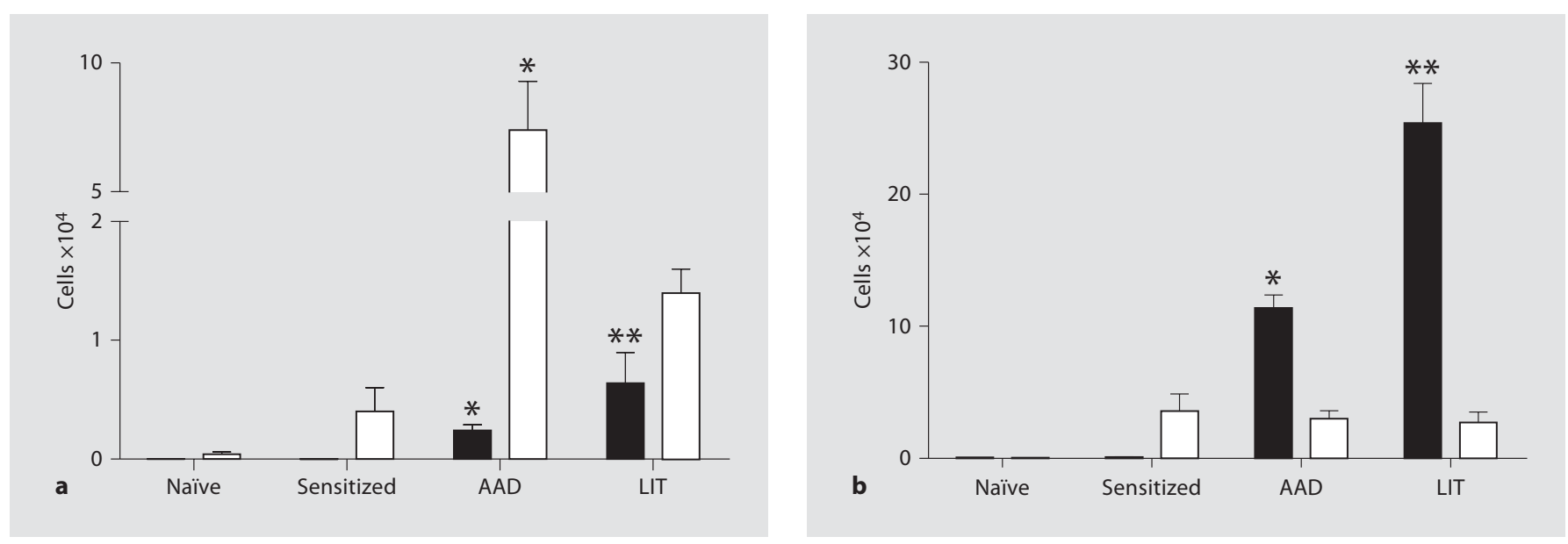

Fig. 7. Foxp3 $+T_{\text {reg }}$ accumulate in BAL and HLN at LIT. Cells recovered from BAL ( $\square$ ) and lung tissue ( $\square$ ) (a), or HLN ( $\square$ ) and ILN ( $\square$ ) (b) were analyzed for CD4 and CD25 expression, along with Foxp3 expression. Three to six mice were used for each analysis. ${ }^{*} \mathrm{p}<0.05$ vs. naïve/sensitized mice, ${ }^{* *} \mathrm{p}<0.05$ vs. all groups.

pattern was observed for the HLN and lung tissue, with the largest increase in CD8+ T cells observed in the HLN (3.1-fold increase; table 1). As with CD8+ T cells, the ratio of CD4+ CD25+ Foxp3+ T cells also increased from AAD to LIT in all lung compartments, with a striking 10 -fold increase in the BAL (table 1). Interestingly, the lung tissue showed a 2 -fold increase in the ratio of putative $T_{\text {reg }}$ from AAD to LIT, whereas the total number of these cells decreased from AAD to LIT, indicating that $\mathrm{T}_{\text {reg }}$ were a prominent proportion of the lung tissue $\mathrm{CD} 4+\mathrm{T}$ cells at LIT.

\section{Discussion}

Long-term aerosol challenge in this OVA-induced model of AAD results in resolution of airway inflammation, reversal of airway hyperresponsiveness and a decrease in $\mathrm{T}_{\mathrm{H}} 2$ cytokines in the BAL $[6,7]$. Analyses of lymphocytes recovered from lung compartments (BAL and lung tissue) indicate that induction and resolution of inflammation correlates with distinct shifts in lymphocyte populations. Local increases in $\mathrm{T}$ and $\mathrm{B}$ cells occurred at $\mathrm{AAD}$ primarily in the BAL, with increases in $\mathrm{CD} 4+\mathrm{CD} 25+\mathrm{T}$ cells in both BAL and lung tissue. At LIT, total numbers of lymphocytes were significantly decreased compared with AAD but still elevated over naïve levels in the BAL. These findings indicate that local increases in lymphocytes correlate with tissue inflammation. Conversely, total numbers of T lymphocytes remain
Table 1. $\mathrm{CD} 8+\mathrm{T}$ cells and the ratio of $\mathrm{CD} 4+\mathrm{CD} 25+$ Foxp3 $+\mathrm{T}$ cells

\begin{tabular}{lrrrrrrrr}
\hline & \multicolumn{3}{c}{ CD8+ T cells } & & & \multicolumn{2}{c}{ CD4+ CD25+ Foxp3+ cells } \\
\cline { 2 - 3 } & HLN & lung tissue & BAL & & HLN & lung tissue & BAL \\
\hline AAD & 32 & 28 & 50 & & 12 & 8 & 2 \\
LIT & 100 & 65 & 132 & & 19 & 17 & 20 \\
Fold change & 3.1 & 2.3 & 2.6 & & 1.6 & 2.1 & 10 \\
\hline
\end{tabular}

Numbers represent the ratio of cells indicated per 100 CD4+ $\mathrm{T}$ cells, calculated by dividing the total number of each cell indicated by the total number of CD4+ T cells. Total numbers were obtained from Foxp3 analysis experiments indicated in Materials and Methods. 'Fold change' represents the increase in cell ratio from AAD to LIT.

elevated in the HLN at LIT, compared with both naïve/ sensitized levels and the ILN. These results indicate that T-cell subsets were selectively increased in the HLN during LIT, independent of lymphocyte populations in systemic lymph nodes.

The observed retention of T lymphocytes in the HLN during LIT appeared in contrast to the resolution of lung inflammation. Adoptive transfer of HLN lymphocytes from AAD and LIT donor mice into RAG1-/- mice was used to assess the functional ability of these lymphocytes to mediate airway inflammation in response to aerosol challenge. Lymphocytes from AAD and LIT HLNs were shown to have disparate pro-inflammatory capabilities, 
in that transfer of AAD HLN lymphocytes resulted in airway inflammation in recipient mice, whereas transfer of LIT HLN lymphocytes did not. These results indicate that a qualitative difference exists in the lymphocyte pool of AAD and LIT HLNs, suggesting that in this model resolution of airway inflammation is not due to mechanisms resulting in a loss of lymphocytes (such as apoptosis of effector T cells).

The maintenance of CD4+ CD25+ T cells in the HLN at LIT suggested the presence of regulatory T cells, as subsets of these cells are known to constitutively express CD25 [32]. We therefore hypothesized that deletion of these cells in vivo would result in the reestablishment of airway eosinophilia. To test this hypothesis, mice were treated with the anti-CD25 antibody PC61 on day 21 of aerosol exposure in an attempt to affect airway eosinophilia at LIT. While PC61 treatment resulted in the in vivo deletion of CD4+ CD25+ T cells at LIT (data not shown), it did not result in the reestablishment of airway eosinophilia. As CD25 is expressed on both $\mathrm{T}_{\text {reg }}$ and activated $\mathrm{T}_{\text {eff }}$, it was possible that the PC61 treatment was having a negative effect on $\mathrm{T}_{\text {eff }}$ activation in this experiment. To address this, mice were treated with PC61 prior to sensitization in an attempt to selectively delete $\mathrm{T}_{\text {reg }}$ without affecting the $\mathrm{T}_{\text {eff-cell pool. PC61 treatment of }}$ mice prior to sensitization resulted in an exacerbation of inflammation at both AAD and LIT, as evidenced by increased BAL eosinophilia. These results indicate that $\mathrm{CD} 4+\mathrm{CD} 25+\mathrm{T}_{\text {reg }}$ present prior to sensitization influence the severity of airway inflammation in this model. Interestingly, CD4+CD25+ T cells were observed in local and systemic tissues in mice treated with PC61 prior to sensitization at the time of sacrifice (data not shown), suggesting that upregulation of CD25 on $\mathrm{T}_{\text {eff }}$ in this model correlates with airway inflammation.

At AAD, Foxp3+ T cells increased in the BAL and HLN compared to levels observed in naïve or sensitizedonly mice. These cells increased further during LIT, indicating an increase in $\mathrm{T}_{\text {reg }}$ in response to chronic aerosol exposure and subsequent resolution of inflammation. While sensitization resulted in a detectable population of $\mathrm{T}_{\text {reg }}$ in the ILN, the total numbers of these cells did not increase during either AAD or LIT. Thus, the expansion of $\mathrm{T}_{\text {reg }}$ during AAD and LIT was restricted to the local lung environment and HLN. The increase in $T_{\text {reg }}$ from AAD to LIT suggests that these cells may play a role in either the development or maintenance of LIT.

Our previous studies indicate that LIT was not due to clonal deletion or anergy, since discontinuation of antigen exposure and subsequent rechallenge with aerosol- ized antigen resulted in the recurrence of airway inflammation [7]. This renewed inflammation did not require resensitization with OVA-alum, suggesting that primed OVA-specific $\mathrm{T}_{\text {eff }}$ were maintained in the mice throughout the development of LIT. An alternative mechanism is that active suppression mediated by $\mathrm{T}_{\text {reg }}$ may be responsible for the resolution of airway inflammation and the development of LIT. $\mathrm{T}_{\text {reg }}$ have been shown to suppress airway responses to inhaled antigens in numerous adoptive transfer models $[14,18,22]$, and depletion of $\mathrm{T}_{\text {reg }}$ populations exacerbates airway inflammation in mice [17]. In the present study, $\mathrm{T}_{\text {reg }}(\mathrm{CD} 4+\mathrm{CD} 25+$ Foxp3 $+\mathrm{T}$ cells) were found to be elevated in the BAL and HLN at AAD and LIT, and were also increased as a percentage of the total CD4+ T-cell population.

Our model of LIT is unique since tolerance develops subsequent to a $\mathrm{T}_{\mathrm{H}} 2$ inflammatory response in the lung. Oral tolerance mechanisms have been shown to block the development of $\mathrm{AAD}$, as long as oral antigen is given prior to the development of inflammation [33-36]. However, in contrast to our model, oral administration of antigen after the disease process has begun results in an exacerbation of inflammation [5]. Oral tolerance studies identified a population of $\mathrm{T}_{\text {reg }}$ that were induced by standard immunization of antigen with adjuvant [25]; these findings are consistent with our results in the ILN concerning the expansion of Foxp3+ T cells in response to sensitization. Also, aerosol challenge with certain model antigens (such as OVA) prior to sensitization induces CD4+ T cellmediated tolerance to subsequent challenges [37, 38]. In these studies, the local draining lymph nodes of the lung are essential to the development of inhalational tolerance, as removal of these nodes results in a block of tolerance induction $[39,40]$. These findings correlate with our data concerning Foxp3+ T-cell expansion in the HLN at LIT, further reinforcing the importance of the lymph node as either the site of proliferation for $T_{\text {reg }}$, or as an important site of regulatory function in vivo.

While CD4+ CD25+ Foxp3+ $\mathrm{T}_{\text {reg }}$ were increased in BAL and HLN during LIT, an opposite pattern was observed for the lung tissue, where the peak increase of total numbers of $\mathrm{T}_{\text {reg }}$ subsets was at AAD. This finding appears to counter the role of $\mathrm{T}_{\text {reg }}$ in the resolution of airway inflammation; however, it may in fact be indicative of the trafficking patterns of $\mathrm{T}_{\text {reg }}$ during LIT. Total numbers of both CD4+ CD25+ T cells and CD4+ CD25+ Foxp3+ T cells are statistically equivalent in the lung tissue and BAL during LIT, suggesting that these $\mathrm{T}_{\text {reg }}$ are being selectively retained in the BAL during LIT. Additionally, Foxp3+ cells in the CD4+ CD25+ T-cell subset were increased as 
a percentage of the population in both the BAL and lung tissue at AAD and LIT. Recent studies of CD8+ T-cell responses to viral infection indicate that protective immunity is maintained in the presence of long-term antigen presentation by cell trafficking predominantly to the BAL and HLN [41]. Increases in $T_{\text {reg }}$ in the BAL and HLN during LIT in this model may be indicative of a similar pattern for $T_{\text {reg, }}$, in that their presence in the airways and draining lymph nodes provide surveillance to inhaled substances and thereby mediate either a first line of defense $\left(\mathrm{T}_{\text {eff }}\right)$ or of immune suppression $\left(\mathrm{T}_{\text {reg }}\right)$. Also, the decrease in CD4+ $\mathrm{T}$ cells in the BAL at LIT concomitant with an increase in Foxp3+ T cells may indicate that apoptosis of $\mathrm{T}_{\text {eff }}$ in the lung may play an important role in the resolution of inflammation. However, the maintenance of CD4+ T cells in the HLN at LIT suggests that a similar phenomenon in the lymph nodes may not be occurring.

To assess the functionality of putative $\mathrm{T}_{\text {reg }}$ subsets during AAD and LIT, CD4+ CD25+ T cells from the HLN of AAD and LIT mice were assessed in an in vitro $T_{\text {reg }}$ functional assay. CD4+ CD25+ T cells from both AAD and LIT HLN exhibited suppressive activity in vitro, and this ability was comparable to splenic CD4+ CD25+ T cells from naïve mice when used in similar cell numbers. $\mathrm{CD} 4+\mathrm{CD} 25+\mathrm{T}$ cells may represent a mix of $\mathrm{T}_{\text {eff }}$ and $\mathrm{T}_{\text {reg }}$ cells, as CD25 is the $\alpha$ subunit of the IL-2 receptor and is upregulated on activated T cells after TCR stimulation [42]. We have shown that AAD HLN contained a population of Foxp3 $+\mathrm{T}_{\text {reg; }}$; however, these cells were unable to suppress inflammation in vivo. LIT was associated with an expansion of $\mathrm{T}_{\text {reg }}$ cells, along with resolution of airway inflammation in vivo. The increase in the ratio of $\mathrm{T}_{\text {reg }}$ to $\mathrm{CD} 4+\mathrm{T}$ cells in the lung compartments from AAD to LIT is intriguing, especially the 10 -fold increase in the $\mathrm{BAL}$, and may provide some insights regarding the mechanism of regulation or its dependence upon in vivo cellular proportions. These observations were consistent with seminal work by Thornton and Shevach [31] showing that $\mathrm{T}_{\text {reg }}$ suppress in a dose-dependent manner in vitro. These findings suggest that local increases in functional $\mathrm{T}_{\text {reg }}$ are required for the resolution of airway inflammation and the development of LIT.

While our results suggested an important role for $\mathrm{CD} 4+\mathrm{T}_{\text {reg, }}$, other suppressive lymphocytes may have contributed to the development of LIT. Increased numbers of CD8+ T cells in the BAL and HLN at LIT also correlated with the resolution of airway inflammation. Suppressor $\mathrm{CD} 8+\mathrm{T}$ cells have been shown to be important in the regulation of many immune responses, including airway inflammation [43-45]. Additionally, B cells have suppres- sive activity in numerous mouse models [46], including allergic airway inflammation [47, 48]. Regulatory B cells have been shown to control T-cell responses both through Fas ligand expression [49] and through secretion of immunosuppressive cytokines such as IL-10 [50-53]. An important caveat for B cells in mouse models is the finding by Hamelmann et al. [54] that eosinophilic lung inflammation in response to OVA does not require B cells. Although LIT has been shown to develop in IL-10 knockout mice [29], this does not rule out a possible role of B cells as immunosuppressive APCs in this model. Our results indicated that a population of B cells remained elevated in the BAL at LIT, suggesting that these B cells could play a role in the development of LIT either directly or by acting as APCs for $\mathrm{T}_{\text {reg. }}$. Further studies aimed at assessing the role of CD8+ T cells and B cells in the resolution of airway inflammation are needed to address this question.

In summary, our findings indicate that at the LIT stage, elevated levels of $\mathrm{T}$ and $\mathrm{B}$ lymphocytes were maintained in the HLN above naïve levels, demonstrating a local retention of lymphocytes during resolution of airway inflammation. Systemic lymph nodes were unchanged during LIT, indicating that this retention of lymphocytes was a local phenomenon. Finally, $\mathrm{T}_{\text {reg }}$ were shown to be increased and retained in the BAL and HLN during LIT, suggesting either local expansion or recruitment to the lung, where they may play a role in the resolution of airway inflammation. These results suggest that the resolution of airway inflammation requires the local accumulation of lymphocytes with suppressor function in this model.

\section{Acknowledgments}

The authors would like to thank Robert Clark, MD, for the generous use of materials and equipment, and Irving Goldschneider, MD, for critical review of the manuscript. This work was supported by NIH/AI R01 HL-43573.

References

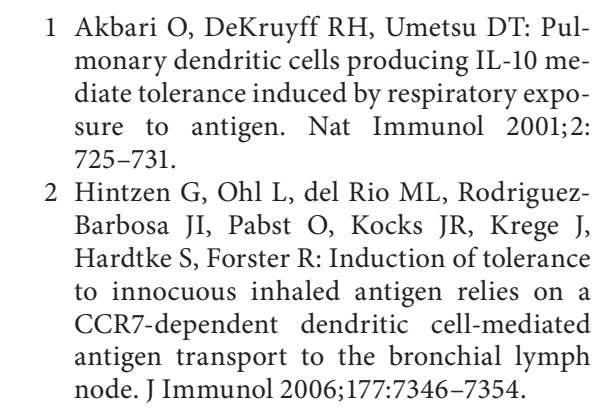

Int Arch Allergy Immunol 2008;145:231-243 
3 Lambrecht BN: Dendritic cells and the regulation of the allergic immune response. Allergy 2005;60:271-282.

4 Faria AM, Weiner HL: Oral tolerance. Immunol Rev 2005;206:232-259.

5 Russo M, Nahori MA, Lefort J, Gomes E, de Castro Keller A, Rodriguez D, Ribeiro OG, Adriouch S, Gallois V, de Faria AM, Vargaftig BB: Suppression of asthma-like responses in different mouse strains by oral tolerance. Am J Respir Cell Mol Biol 2001;24:518-526.

-6 Yiamouyiannis CA, Schramm CM, Puddington L, Stengel P, Baradaran-Hosseini E, Wolyniec WW, Whiteley HE, Thrall RS: Shifts in lung lymphocyte profiles correlate with the sequential development of acute allergic and chronic tolerant stages in a murine asthma model. Am J Pathol 1999;154:19111921.

-7 Schramm CM, Puddington L, Wu C, Guernsey L, Gharaee-Kermani M, Phan SH, Thrall RS: Chronic inhaled ovalbumin exposure induces antigen-dependent but not antigenspecific inhalational tolerance in a murine model of allergic airway disease. Am J Pathol 2004;164:295-304.

-8 Wu CA, Puddington L, Whiteley HE, Yiamouyiannis CA, Schramm CM, Mohammadu F, Thrall RS: Murine cytomegalovirus infection alters Th1/Th2 cytokine expression, decreases airway eosinophilia, and enhances mucus production in allergic airway disease. J Immunol 2001;167:2798-2807.

-9 Epstein MM: Do mouse models of allergic asthma mimic clinical disease? Int Arch Allergy Immunol 2004;133:84-100.

10 Kips JC, Anderson GP, Fredberg JJ, Herz U, Inman MD, Jordana M, Kemeny DM, Lotvall J, Pauwels RA, Plopper CG, Schmidt D, Sterk PJ, Van Oosterhout AJ, Vargaftig BB, Chung KF: Murine models of asthma. Eur Respir J 2003;22:374-382.

-11 Gajewska BU, Swirski FK, Alvarez D, Ritz SA, Goncharova S, Cundall M, Snider DP, Coyle AJ, Gutierrez-Ramos JC, Stampfli MR, Jordana M: Temporal-spatial analysis of the immune response in a murine model of ovalbumin-induced airways inflammation. Am J Respir Cell Mol Biol 2001;25:326-334.

-12 Sakai K, Yokoyama A, Kohno N, Hamada H, Hiwada K: Prolonged antigen exposure ameliorates airway inflammation but not remodeling in a mouse model of bronchial asthma. Int Arch Allergy Immunol 2001; 126:126-134.

-13 Swirski FK, Sajic D, Robbins CS, Gajewska BU, Jordana M, Stampfli MR: Chronic exposure to innocuous antigen in sensitized mice leads to suppressed airway eosinophilia that is reversed by granulocyte macrophage colony-stimulating factor. J Immunol 2002;169: 3499-3506.
14 Chen W, Jin W, Hardegen N, Lei KJ, Li L, Marinos N, McGrady G, Wahl SM: Conversion of peripheral CD4+CD25- naive T cells to $\mathrm{CD} 4+\mathrm{CD} 25$ + regulatory T cells by TGF- $\beta$ induction of transcription factor Foxp3. J Exp Med 2003;198:1875-1886.

15 Zuany-Amorim C, Sawicka E, Manlius C, Le Moine A, Brunet LR, Kemeny DM, Bowen G, Rook G, Walker C: Suppression of airway eosinophilia by killed Mycobacterium vaccaeinduced allergen-specific regulatory T-cells. Nat Med 2002;8:625-629.

16 Hadeiba H, Locksley RM: Lung CD25 CD4 regulatory $\mathrm{T}$ cells suppress type 2 immune responses but not bronchial hyperreactivity. J Immunol 2003;170:5502-5510.

17 Lewkowich IP, Herman NS, Schleifer KW, Dance MP, Chen BL, Dienger KM, Sproles AA, Shah JS, Kohl J, Belkaid Y, Wills-Karp $\mathrm{M}$ : CD4+CD25+ T cells protect against experimentally induced asthma and alter pulmonary dendritic cell phenotype and function. J Exp Med 2005;202:1549-1561.

18 Unger WW, Jansen W, Wolvers DA, van Halteren AG, Kraal G, Samsom JN: Nasal tolerance induces antigen-specific CD4+CD25regulatory $\mathrm{T}$ cells that can transfer their regulatory capacity to naive $\mathrm{CD} 4+\mathrm{T}$ cells. Int Immunol 2003;15:731-739.

19 Shi HZ, Qin XJ: CD4CD25 regulatory T lymphocytes in allergy and asthma. Allergy 2005;60:986-995.

20 Yssel H, Lecart S, Pene J: Regulatory T cells and allergic asthma. Microbes Infect 2001;3: 899-904.

-21 Hawrylowicz CM: Regulatory T cells and IL10 in allergic inflammation. J Exp Med 2005; 202:1459-1463.

-22 Akbari O, Freeman GJ, Meyer EH, Greenfield EA, Chang TT, Sharpe AH, Berry G, DeKruyff RH, Umetsu DT: Antigen-specific regulatory $\mathrm{T}$ cells develop via the ICOSICOS-ligand pathway and inhibit allergeninduced airway hyperreactivity. Nat Med 2002;8:1024-1032.

23 Kearley J, Barker JE, Robinson DS, Lloyd CM: Resolution of airway inflammation and hyperreactivity after in vivo transfer of $\mathrm{CD} 4+\mathrm{CD} 25+$ regulatory $\mathrm{T}$ cells is interleukin 10 dependent. J Exp Med 2005;202:1539_ 1547.

24 Barbey C, Donatelli-Dufour N, Batard P, Corradin G, Spertini F: Intranasal treatment with ovalbumin but not the major $\mathrm{T}$ cell epitope ovalbumin 323-339 generates interleukin-10 secreting $\mathrm{T}$ cells and results in the induction of allergen systemic tolerance. Clin Exp Allergy 2004;34:654-662.

25 Mucida D, Kutchukhidze N, Erazo A, Russo M, Lafaille JJ, Curotto de Lafaille MA: Oral tolerance in the absence of naturally occurring Tregs. J Clin Invest 2005;115:19231933.
26 Nakamura K, Kitani A, Fuss I, Pedersen A, Harada N, Nawata H, Strober W: TGF- $\beta 1$ plays an important role in the mechanism of $\mathrm{CD} 4^{+} \mathrm{CD} 25^{+}$regulatory $\mathrm{T}$ cell activity in both humans and mice. J Immunol 2004;172: 834-842.

27 Nakamura K, Kitani A, Strober W: Cell contact-dependent immunosuppression by $\mathrm{CD} 4^{+} \mathrm{CD} 25^{+}$regulatory $\mathrm{T}$ cells is mediated by cell surface-bound transforming growth factor $\beta$. J Exp Med 2001;194:629-644.

-28 Ostroukhova M, Seguin-Devaux C, Oriss TB, Dixon-McCarthy B, Yang L, Ameredes BT, Corcoran TE, Ray A: Tolerance induced by inhaled antigen involves $\mathrm{CD} 4^{+} \mathrm{T}$ cells expressing membrane-bound TGF- $\beta$ and FOXP3. J Clin Invest 2004;114:28-38.

29 Kabbur PM, Carson WFI, Guernsey L, Secor ER Jr, Thrall RS, Schramm CM: Interleukin10 does not mediate inhalational tolerance in a chronic model of ovalbumin-induced allergic airway disease. Cell Immunol 2006; 239:67-74.

30 Wohlfert EA, Callahan MK, Clark RB: Resistance to $\mathrm{CD} 4^{+} \mathrm{CD} 25^{+}$regulatory $\mathrm{T}$ cells and TGF- $\beta$ in Cbl-b ${ }^{-1-}$ mice. J Immunol 2004; 173:1059-1065.

31 Thornton AM, Shevach EM: $\mathrm{CD} 4^{+} \mathrm{CD} 25^{+}$ immunoregulatory $\mathrm{T}$ cells suppress polyclonal $\mathrm{T}$ cell activation in vitro by inhibiting interleukin 2 production. J Exp Med 1998; 188:287-296.

32 Sakaguchi S, Sakaguchi N, Asano M, Itoh M, Toda M: Immunologic self-tolerance maintained by activated T cells expressing IL-2 receptor alpha-chains (CD25). Breakdown of a single mechanism of self-tolerance causes various autoimmune diseases. J Immunol 1995;155:1151-1164.

- 33 McMenamin C, Pimm C, McKersey M, Holt PG: Regulation of IgE responses to inhaled antigen in mice by antigen-specific gamma delta T cells. Science 1994;265:1869-1871.

- 34 Seymour BW, Gershwin LJ, Coffman RL: Aerosol-induced immunoglobulin (Ig)-E unresponsiveness to ovalbumin does not require $\mathrm{CD}^{+}$or T cell receptor (TCR) $-\gamma / \delta^{+} \mathrm{T}$ cells or interferon (IFN)- $\gamma$ in a murine model of allergen sensitization. J Exp Med 1998; 187:721-731.

- 35 Nakao A, Kasai M, Kumano K, Nakajima H, Kurasawa K, Iwamoto I: High-dose oral tolerance prevents antigen-induced eosinophil recruitment into the mouse airways. Int Immunol 1998;10:387-394.

-36 van Halteren AG, van der Cammen MJ, Cooper D, Savelkoul HF, Kraal G, Holt PG: Regulation of antigen-specific IgE, IgG1, and mast cell responses to ingested allergen by mucosal tolerance induction. I Immunol 1997;159:3009-3015. 
-37 Swirski FK, Gajewska BU, Alvarez D, Ritz SA, Cundall MJ, Cates EC, Coyle AJ, Gutierrez-Ramos JC, Inman $\mathrm{MD}$, Jordana $\mathrm{M}$, Stampfli MR: Inhalation of a harmless antigen (ovalbumin) elicits immune activation but divergent immunoglobulin and cytokine activities in mice. Clin Exp Allergy 2002;32: 411-421.

>38 Tsitoura DC, DeKruyff RH, Lamb JR, Umetsu DT: Intranasal exposure to protein antigen induces immunological tolerance mediated by functionally disabled CD4+ T cells. J Immunol 1999;163:2592-2600.

-39 Unger WW, Hauet-Broere F, Jansen W, van Berkel LA, Kraal G, Samsom JN: Early events in peripheral regulatory $\mathrm{T}$ cell induction via the nasal mucosa. J Immunol 2003;171: 4592-4603.

-40 Wolvers DA, Coenen-de Roo CJ, Mebius RE, van der Cammen MJ, Tirion F, Miltenburg AM, Kraal G: Intranasally induced immunological tolerance is determined by characteristics of the draining lymph nodes: Studies with OVA and human cartilage gp-39. J Immunol 1999;162:1994-1998.

-41 Zammit DJ, Turner DL, Klonowski KD, Lefrancois L, Cauley LS: Residual antigen presentation after influenza virus infection affects CD8 T cell activation and migration. Immunity 2006;24:439-449.
42 Malek TR, Schmidt JA, Shevach EM: The murine IL 2 receptor. III. Cellular requirements for the induction of IL 2 receptor expression on $\mathrm{T}$ cell subpopulations. J Immunol 1985;134:2405-2413.

43 Maile R, Pop SM, Tisch R, Collins EJ, Cairns BA, Frelinger JA: Low-avidity CD8lo T cells induced by incomplete antigen stimulation in vivo regulate naive higher avidity CD8hi $\mathrm{T}$ cell responses to the same antigen. Eur J Immunol 2006;36:397-410.

44 Schaller MA, Lundy SK, Huffnagle GB, Lukacs NW: CD8+ T cell contributions to allergen induced pulmonary inflammation and airway hyperreactivity. Eur J Immunol 2005;35:2061-2070.

45 Stock P, Kallinich T, Akbari O, Quarcoo D, Gerhold K, Wahn U, Umetsu DT, Hamelmann E: $\mathrm{CD}^{+} \mathrm{T}$ cells regulate immune responses in a murine model of allergeninduced sensitization and airway inflammation. Eur J Immunol 2004;34:1817-1827.

$\checkmark 46$ Mizoguchi A, Bhan AK: A case for regulatory B cells. J Immunol 2006;176:705-710.

47 Lundy SK, Berlin AA, Martens TF, Lukacs NW: Deficiency of regulatory B cells increases allergic airway inflammation. Inflamm Res 2005;54:514-521.

48 Tsitoura DC, Yeung VP, DeKruyff RH, Umetsu DT: Critical role of B cells in the development of $\mathrm{T}$ cell tolerance to aeroallergens. Int Immunol 2002;14:659-667.
49 Lundy SK, Lerman SP, Boros DL: Soluble egg antigen-stimulated $\mathrm{T}$ helper lymphocyte apoptosis and evidence for cell death mediated by FasL ${ }^{+} \mathrm{T}$ and $\mathrm{B}$ cells during murine Schistosoma mansoni infection. Infect Immun 2001;69:271-280.

50 Fillatreau S, Sweenie CH, McGeachy MJ, Gray D, Anderton SM: B cells regulate autoimmunity by provision of IL-10. Nat Immunol 2002;3:944-950.

>51 Gillan V, Lawrence RA, Devaney E: B cells play a regulatory role in mice infected with the L3 of Brugia pahangi. Int Immunol 2005; 17:373-382.

52 Mauri C, Gray D, Mushtaq N, Londei M: Prevention of arthritis by interleukin 10-producing B cells. J Exp Med 2003;197:489501.

53 Mizoguchi A, Mizoguchi E, Takedatsu H, Blumberg RS, Bhan AK: Chronic intestinal inflammatory condition generates IL-10producing regulatory $\mathrm{B}$ cell subset characterized by CD1d upregulation. Immunity 2002;16:219-230.

54 Hamelmann E, Takeda K, Schwarze J, Vella AT, Irvin CG, Gelfand EW: Development of eosinophilic airway inflammation and airway hyperresponsiveness requires interleukin-5 but not immunoglobulin E or B lymphocytes. Am J Respir Cell Mol Biol 1999;21: 480-489. 